OECD Economics Department Working Papers No. 49

\title{
Are Commodity Prices Leading Indicators of OECD Prices?
}

Martine Durand, Sveinbjörn Blöndal 


\section{OECD \\ DEPARTMENT \\ OF ECONOMICS AND STATISTICS}

\section{WORKING PAPERS}

NO. 49: ARE COMMODITY PRICES LEADING INDICATORS OF OECD PRICES?

by

Martine Durand

(General Economics Division)

Sveinbjörn Blöndal

(Country Studies II Division)

February 1988

OCLDE

imitimi

OESD 

GENERAL DISTRIBUTION

\section{ECONOMICS AND STATISTICS DEPARTMENT}

\section{WORKING PAPERS}

This series of Working Papers is designed to make available, to a wider readership, selected studies which the Department has prepared for use within OECD. Authorship is generally collective, but main individual authors are named. The Papers are generally available in their original language, English or French, with a summary in the other.

Comment on the Papers is invited, and may be sent to OECD, Department of Economics and Statistics, 2 rue André Pascal, 75775 Paris Cedex 16, France. Additional copies of the Papers on a limited basis can be forwarded on request.

ORGANISATION FOR ECONOMIC CO-OPERATION AND DEVELOPMENT

Copyright OECD 1986

10799 
This paper examines the hypothesis that commodity price trends are useful indicators of OECD price developments. After a discussion of statistical techniques to assess the time series properties of individual price indices, integration and cointegration tests are conducted on a wide set of individual and aggregate commodity price indices and consumer price indices for the major seven OECD countries. The results of the analysis suggest that there is no clear evidence of any equilibrium relationship between levels of consumer and commodity prices. But relations between changes in a number of commodity prices such as metals and agricultural raw material prices and consumer prices may be established. The stability over time of such relationships is also tested.

$$
* * *
$$

Cet article tente de déterminer si les prix des produits de base peuvent jouer un rôle d'indicateurs avancés pour les évolutions de prix dans les grands pays de l'OCDE. Après discussion des techniques statistiques permettant d'établir les propriétés temporelles des series de prix utilisées, les tests d'intégration et de cointégration sont appliqués à un nombre important d'indices de prix élémentaires et agrégés de produits de base et d'indices de prix à la consommation. Les résultats de cette analyse indiquent qu'il $n^{\prime}$ existe pas de relation en niveau entre indices de prix à la consommation et prix de produits de base. Par contre, les variations dans les prix de certains produits comme ceux des métaux et des produits agricoles bruts peuvent être retenus comme indicateurs avancés du taux d'inflation dans les pays de l'OCDE. La stabilité temporelle de telles relations est également tẹstée. 
ARE COMMODITY PRICES LEADING INDICATORS OF OECD PRICES?

by

Martine Durand

(General Economics Division)

Sveinbjörn Blöndal

(Country Studies II Division)

We are very grateful to Jeffrey Shafer who initiated this project and gave many helpful comments. We also wish to acknowledge David Coe for discussions and comments and Anick Lotrous for statistical assistance. 

ARE COMMODITY PRICES LEADING INDICATORS OF OECD PRICES?

TABLE OF CONTENTS

$\underline{\text { Page }}$

I. INTRODUCTION AND SUMMARY 2

II. METHODOLOGICAL ISSUES

III. EMPIRICAL RESULTS ? $\quad 6$

A. Description of the data 6

B. Integration and cointegration tests 7

C. Granger-causality and stability tests $\quad 9$

NOTES 17

$\begin{array}{ll}\text { REFERENCES } & 18\end{array}$

TABLES

1. First-order integration tests 9

2. Cointegration tests between aggregate
commodity and $O E C D$ price levels

3. Granger-causality tests on commodity price inflation
and major seven OECD countries CPI inflation

4. Stability tests 16

CHART

A. Developments in commodity and consumer price indices 


\section{INTRODUCTION AND SUMMARY}

Commodity price series have long been scrutinised for indications of the future course of inflation or deflation. Recently, there has been particular interest in their usefulness as an advance indicator of inflation in the process of multilateral surveillance of economic policies. U.S. Treasury Secretary James Baker and U.K. Chancellor of the Exchequer Nigel Lawson both made proposals along these lines at the September 1987 annual meetings of the International Monetary Fund and the World Bank [Baker (1987), Lawson (1987)]. Secretary Baker suggested the use of commodity prices, including gold, in assessing the inflation outlook for each country. Chancellor Lawson proposed the use of a commodity price index as a global indicator or early warning signal of the risks of inflation and disinflation for major industrial countries as a group. Both ministers were responding to the need for a way to gauge the appropriate overall balance of macroeconomic policies between stimulus and restraint in the context of coordinated efforts to reduce and contain imbalances among the major economies and promote greater stability of exchange rates.

In recent years, a number of other mechanisms have been proposed to counter any tendency for co-ordinated policies to have either an inflationary or deflationary bias. For example, McKinnon (1984) advocated targeting world money supply to anchor nominal world prices but has since abandoned his earlier proposal [McKinnon (1987)] in favour of targeting the average price of traded goods directly, thus allowing for velocity shifts. To the same end, Williamson and Miller (1987) have suggested a nominal expenditure target in conjunction with stable exchange rates. However, a nominal expenditure target as an operational guide for policy is of limited practical use owing to lags in the availability of national income accounts and frequent revistons, as well as to uncertainty concerning its future evolution for any given policy setting. Hence the search for indicators around which policies could be co-ordinated.

A number of economic arguments can be advanced in support of the hypothesis that commodity price developments predate movements in the general price level. Many commodity prices are determined in auction markets which respond quickly to changes in supply and demand, in contrast to prices in customer markets for processed goods. This distinction is emphasised by, among others, Bosworth and Lawrence (1982), and Beckerman and Jenkinson (1986). Provided conditions in commodity markets reflect aggregate supply and demand in the whole economy, an increase in aggregate demand, which might eventually translate into higher price inflation, might be expected to show up much earlier in commodity prices. Another characteristic of commodity prices which may make them suitable leading indicators is their forward-looking element, arising from their storability -- including, in the case of minerals, the existence of unextracted reserves. Hence, commodity stocks, and claims on them which are traded in future markets, are similar to financial assets in the sensitivity of their prices to expectations of future economic conditions. For example, provided that such markets are efficient, an increase in expectations of inflation should immediately be reflected in higher commodity prices. If these expectations are rational, such price movements could provide information about future prices of use to policymakers. Van Duyne (1979) and Frankel and Hardouvelis (1983) have emphasized this asset character of commodities. Finally, a more traditional argument for relying on commodity 
prices in predicting price developments is that they enter, generally with a lag, as costs in output price equations (1). Thus, current commodity price movements have a direct effect on future movements of general price indices.

Commodity prices, however, also have potential weaknesses as indicators of general price developments. Supply conditions in commodity markets can deviate significantly from aggregate supply in an individual economy or the world economy due to specific factors such as climate. In addition, movements in non-commodity costs, particularly labour costs, can dominate the influence of past commodity prices on current prices. And either market inefficiency, expectational aberrations or both could reduce the indicator value of commodity price movements. In the end, the quality of commodity prices as a leading indicator of general price developments can only be determined by reference to empirical evidence as to how they would have performed in the past.

An. important distinction needs to be made between the hypothesis of commodity price levels being leading indicators for general price levels, and the hypothesis that commodity price inflation leads general price inflation (i.e., rates of change in price levels). The suggestion that the trend in commodity prices could serve as a leading indicator for general prices, referred to above, appears to require a relationship between the levels of the two : series. This in turn implies that the long-run,terms of trade are fixed, and completely independent of economic factors, such as differential productivity growth. This is a very restrictive assumption, but one which would strengthen the possible role of commodity prices as indicators of general price developments since observed deviations from a long-run level relationship could be expected to be closed in the future.

Even if a level relationship cannot be established between commodity prices and aggregate prices, a relationship between their changes could still make commodity price changes informative as to future inflation movements. In either case, ' however, at least some of the disturbances that affect both time series must appear earlier in the commodity series than in the aggregate price series. Tests for such leads in innovations, generally referred to as "Granger causality" tests, are not tests for causality in a structural sense. Moreover, in the present context evidence that disturbances in commodity prices do or do not lead aggregate price developments, does not settle the question of whether commodity prices contain useful information about future general price developments. It may be that monetary authorities are already making full use of this information to attempt to stabilise the price level. In this case, disturbances in commodity prices would call forth a monetary response that would neutralise the disturbance before it could be reflected in the general inflation rate. Nevertheless, the tests are useful in establishing the extent to which commodity prices have been given too little weight by policymakers in the past. Thus, they are appropriate for examining the question of whether policymaking might be improved by giving them a more important or more formal role as indicators.

This paper examines this question by exploring bivariate relationships between a number of commodity price indices, both for individual and aggregates of commodities, and consumer price indices in the OECD area (2). The objective is to test whether commodity prices are useful to predict consumer prices, and whether this refers to level or rates of change 
relationships. Although some existing aggregate commodity price indices have been considered, it has not been attempted to define a new "basket" of commodity prices that could predict OECD consumer prices. As such, it is a reconnaissance rather than an in depth investigation. Many interesting questions are not addressed. Among them are what information commodity prices might add in the context of a larger set of indicators -- a question for multivariate analysis. It seemed that the place to start was to examine bivariate relationships.

The results of these tests can be summarised as follows:

- the levels of all the commodity and consumer price indices are non-stationary, while their inflation rates are without apparent trends;

-- there is little evidence for a level relationship between commodity and consumer price indices, the only exceptions being consumer and gold price indices in the United Kingdom and, in the 1960-1973 period, France;

-- innovations in the inflation of some important metal, food and agricultural raw material prices lead aggregate OECD inflation rates, but the autoregressive relationships are in general unstable over time and subject to two-way intertemporal causation.

Thus there does appear to be useful information about the future course of OECD inflation to be gleaned from the growth of some commodity prices. Developments in some metals, food and agricultural raw materials prices may therefore be a useful supplement to the existing indicators used in the multilateral surveillance process.

Some methodological issues related to tests for discrimination between level and rate of changes bivariate relationships are discussed in the next section. The results from this analysis are presented in the third section, together with "Granger causality" tests and stability tests of the specification most favoured by the data.

\section{METHODOLOGICAL ISSUES}

Secular movements in finite time series with apparent trends can be represented as either deterministic time trends or they can be characterised as being driven by stochastic processes with no tendency to return to a predetermined path, that is, as integrated processes in which errors are cumulative. Despite the common use of deterministic time trends to describe the tendency for macroeconomic time series to deviate cumulatively from their starting level, there is growing evidence that their secular components are better represented as integrated stochastic processes, such as a random walk [Nelson and Plosser, (1982)]. In this study, we assume that the secular behaviour of both commodity and consumer prices is stochastic and not deterministic.

In this context, a necessary condition for commodity price levels to forecast future levels of consumer prices is that they be driven by a common 
integrated process, and therefore the time series, if appropriately scaled, do not drift too far apart, at least in the long run. In other words, non-contemporaneous levels of consumer and commodity prices must form an equilibrium relationship. Under these circumstances, non-contemporaneous values of the same variable should form an equilibrium relationship among themselves, which in turn implies that a contemporaneous relationship must exist between the levels of commodity prices and consumer prices (3). It has been shown that standard test statistics, such as $t$ - and F-ratios, do not possess limiting distributions in the case of mutually trending variables, except under special circumstances, thus invalidating standard statistical inference [Phillips (1986)]. Recently developed tests for cointegration, however, offer a framework to test for the existence of a level relationship among jointly trending variables [Granger (1986), Hendry (1986) and Engle and Granger (1987)]. This strategy is employed below (4).

The cointegration testing strategy starts from the premise that a precondition for the levels of two variables to form an equilibrium relationship is that they both share the same intertemporal characteristics. A dynamic property of a single series can be described by how of ten it needs to be differenced in order to provide a stationary process in which any tendency for errors to cumulate has been eliminated, i.e. by its order of integration (denoted as $I(d)$ where $d$ is the order of integration). Two variables can form an equilibrium relationship only if both are $I(1)$. The order of integration can be inferred from either the sample autocorrelation function [Box and Jenkins (1976)] or by testing for unit roots. The latter method tests the null hypothesis of a process driven by a random walk against the alternative of stationarity. A number of unit root tests have been suggested in the literature [Evans and Savin (1981, 1984), Dickey and Fuller (1979), Sargan and Bhargava (1983) and Phillips (1987)]. In this study we have employed the Durbin-Watson test of Sargan and Bhargava (CRDW) and the adjusted Dickey-Fuller test (ADF). The relevant test statistics can be obtained from standard OLS regression output by running the following regressions:

a) CRDW: $\mathrm{X}_{t}=\mathrm{C}+\mathrm{u}_{\mathrm{t}}$

b) ADF: $\quad \Delta x_{t}=\alpha x_{t-1}+\sum_{j=1}^{p} \Delta x_{t-j}+e_{t}$

where $C$ is a constant, $u$ and $e$ are error terms, and $\Delta$ is the first difference operator. The test statistic for CRDW is the Durbin-Watson coefficient for the regression. Its distribution has been derived by Sargan and Bhargava (1983) who also computed critical values. The distribution of the ADF test statistic, which is the t-ratio associated with $\alpha$, was derived by Dickey and Fuller (1979) (5). The two different test statistics can lead to conflicting inferences since the CRDW test presupposes that both the null and the alternative hypotheses are of the first order, while the ADF test is adjusted for higher order (the $\Delta x$ terms). Which of the two test statistics is more appropriate will thus differ from case to case. If the null hypothesis of a random walk cannot be rejected, the $I(1)$ hypothesis can be tested against a non-stationary first difference [i.e. $I(2)]$ by differencing the $X$ and $\Delta X$ terms in [1]. 
After establishing that two series $X$ and $Y$ are both integrated of the first order, they are candidates for an equilibrium relationship. To gauge whether the variables form a level relationship, the following cointegration regression is run:

$$
X_{t}=a_{0}+a_{1} Y_{t}+u_{t}
$$

An equilibrium relationship is said to exist if the residual from this regression is stationary. As discussed above, standard statistical inference is not valid when the variables are non-stationary and regressions are prone to generate spurious relationships among variables. However, contrary to the spurious regression case, the estimated parameters do converge in probability to constants provided that the variables cointegrate [Phillips (1986)]. Moreover, it has been shown that the convergence is faster than in ordinary regression [Stock (1987)]. These properties suggest that the cointegration regression provides a good estimate of the long-run equilibrium relationship.

The intertemporal properties of the residual in [2], in particular whether it is stationary, can again be determined by any of the unit root test procedures. However, the distribution of the test statistics differ from the univariate case. The critical significance levels now become functions of the data generation process, which is generally unknown. Sargan and Bhargava (1983) computed upper and lower critical bounds for the null hypothesis that the residuals from the cointegration regression is driven by a random walk process. Unfortunately, this leaves a large region where the test would be indeterminate. Exact critical values can be derived by computing probability distributions for each data generating process. Alternatively, it is possible to compute exact critical values using Monte Carlo methods for a given data generating process. Engle and Granger (1987) provide exact critical values for the CRDW and ADF test statistics for two different generating processes. Since exact CRDW critical levels are shown to be very sensitive to the data generating process while the critical levels for the ADF are relatively robust, the ADF test seems more appropriate when the CRDW falls within the indeterminate range.

\section{BMPIRICAL RESULTS}

\section{A. Description of the data}

The tests reported below were conducted on consumer price indices for the major seven OECD countries and their GDP-weighted average (hereafter somewhat loosely referred to as OECD inflation), and individual and aggregate commodity price indices. Aggregate commodity price indices from three different sources have been used: the HWWA (Hamburg Institüt für Weltwirtschaftforschung), the UNCTAD and the IMF price indices. Although they all include total commodity, foodstuff, tropical beverages, agricultural raw materials and metals and minerals price indices (6), they differ in construction, both in terms of weights and commodity coverage, and may thus exhibit different movements over time. In particular, commodities in the UNCTAD and IMF indices are weighted according to trade patterns based on exports whereas the HWWA indices use weights based on imports of primary commodities (7). Since aggregate indices include primary commodity prices 
which have very different characteristics, a number of individual commodity prices used in the construction of the aggregate indices were also considered (8). These are listed in Table 1. For consistency, all CPIs and commodity price indices were expressed in U.S. dollars and were not seasonally adjusted. Given the extreme volatility of the monthly data quarterly data have been used.

When considered at the aggregate level, the first oil shock represents a break in the time profile of the series between 1960 and 1987 (Chart A). For that reason, the study of the intertemporal properties of commodity prices has been conducted over two sub-periods: before and after 1973. The same was done for the CPIs, in order to establish possible relationships between CPIs and commodity prices limited to sub-periods of the sample.

Finally, the analysis of the time series properties conducted here was on the logarithms of the levels of the series (9). The reason for choosing $\log$ levels rather than the levels themselves is because differenced log levels of prices are an approximation of inflation rates, so that while testing for level equilibrium relationships, it is also possible to analyse relationships between inflation rates in CPIs and commodity prices.

\section{B. Integration and cointegration tests}

Table 1 reports the Sargan-Bhargava (CRDW) and adjusted Dickey-Fuller (ADF) test statistics, where the latter have been done with four lags on the $\Delta \mathrm{X}$ term $(j=4$ in [1]). The tests indicate that, without exception, the individual and aggregate commodity price indices are estimated to be at least integrated of first order. They all comfortably pass the tests performed at the 5 per cent confidence level on regressions done over the entire period. When the period is split into two sub-periods, the same results hold with the one exception that the price index of tea is found to be $I(0)$ in the first sub-period, but at least I(1) in the second. The Sargan-Bhargava and Dickey-Fuller tests for a higher degree of integration, with no allowance for lags, clearly reject the hypothesis that commodity prices are $I(2)(10)$. So, in general, the indices have to be differenced once to become stationary processes. The results of the tests for the consumer price indices also lead to the conclusion that country and aggregate CPIs are integrated of first order in the whole period, as well as in the two sub-periods.

The Sargan-Bhargava and adjusted Dickey-Fuller tests for cointegration show that, taken two by two, individual and aggregate CPIs and commodity price indices are generally not cointegrated, in either the whole period or the two sub-periods. There are only two exceptions to this general pattern: the U.K. CPI and the gold price index are cointegrated over the whole period and the French CPI and the gold price index are cointegrated in the first sub-period. Table 2 presents the results of cointegration tests between OECD and aggregate commodity prices; results for the individual commodity price indices and individual country CPIs are available on request.

The conclusion is that there is no evidence of equilibrium level relationships between most of the commodity prices considered here and the major seven countries CPIs. The hypothesis that in the long run the price levels of consumer goods and primary commodities do not significantly depart from each other is therefore rejected. 
Chart A

DEVELOPHENTS IN COMYODITY AND CONSUMER PRICE INDICES
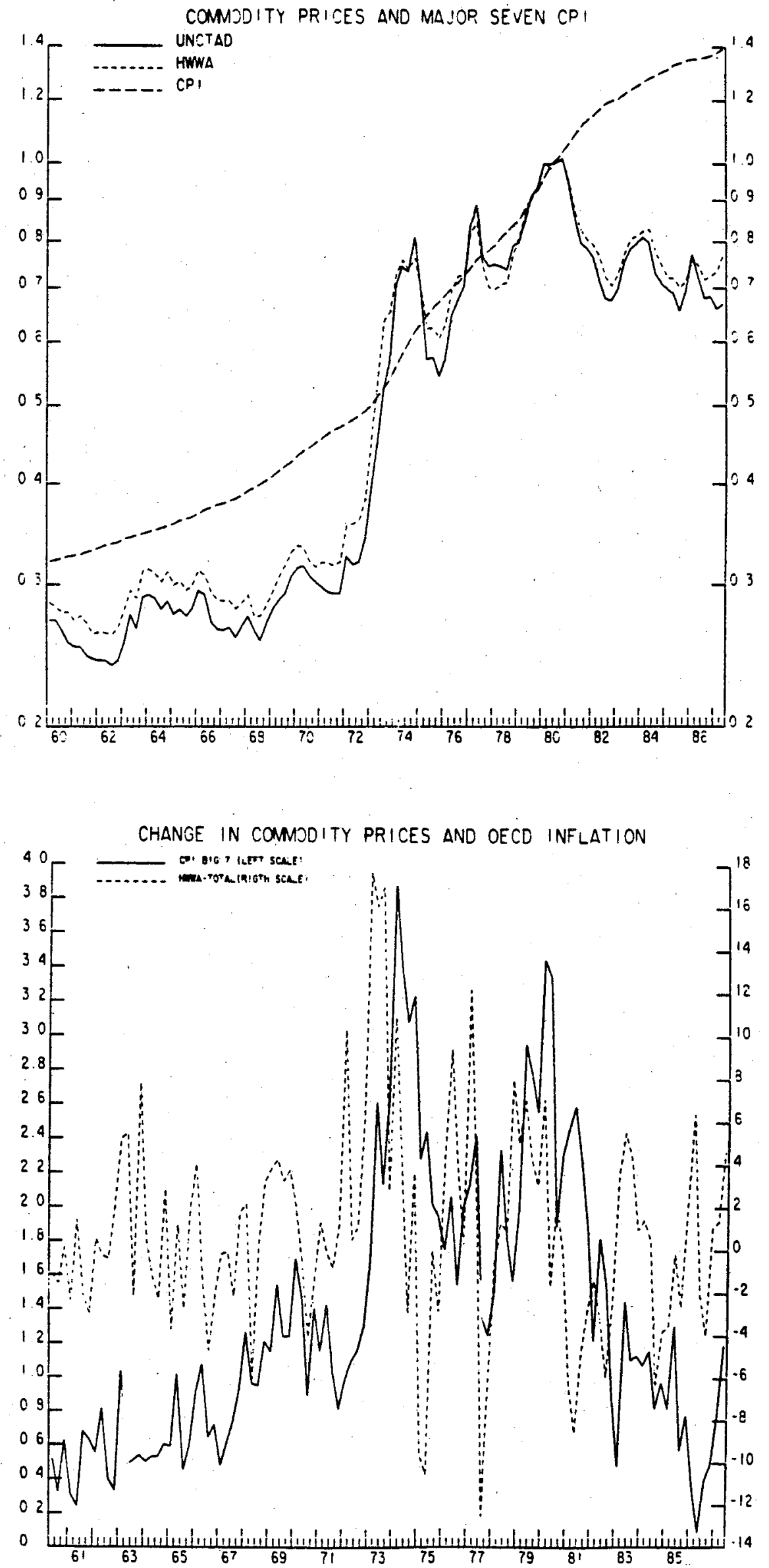
Table 1

FIRST-ORDER INTEGRATION TESTS

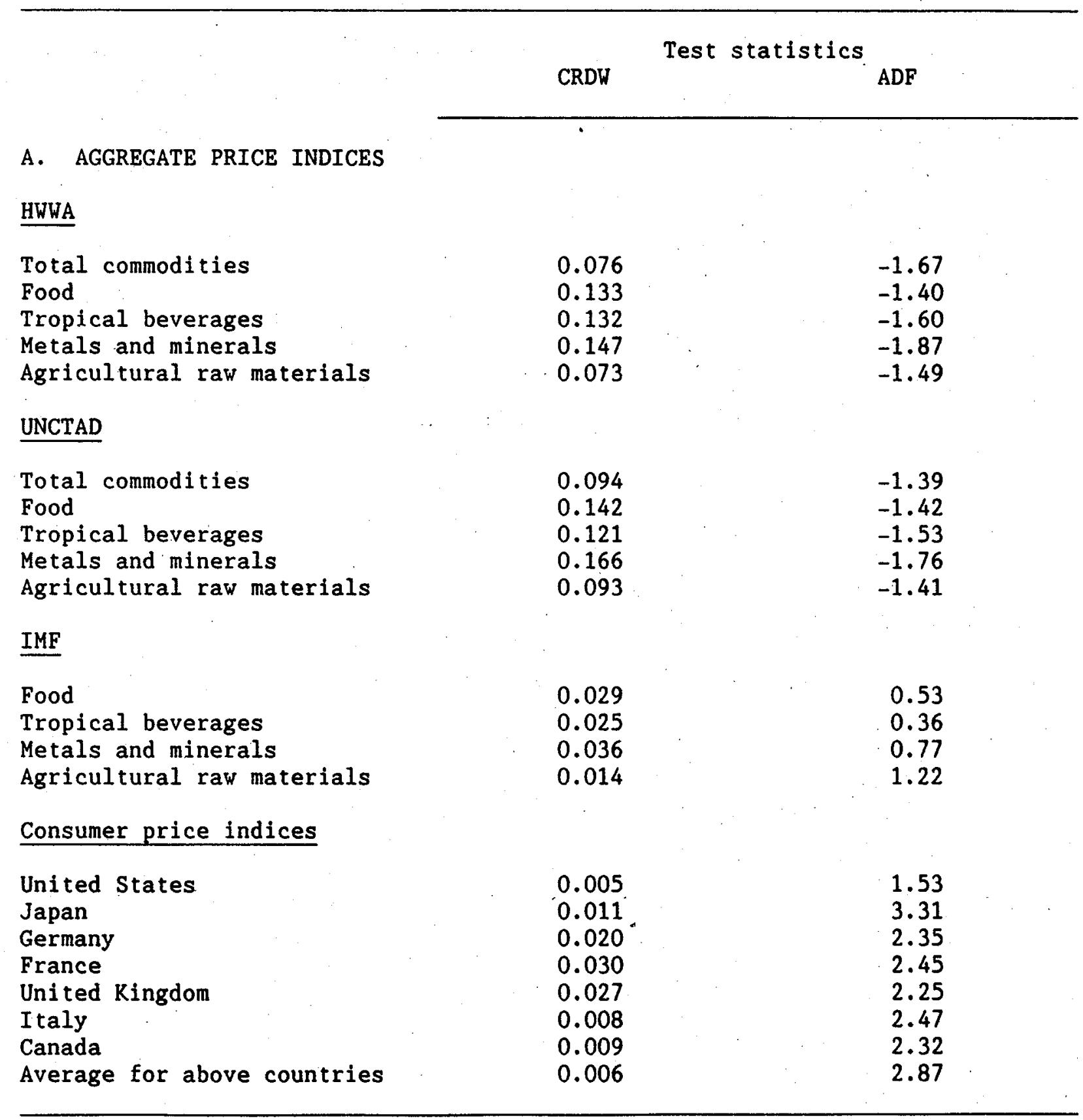


Table 1 (continued)

CRDW Test statistics ADF

B. INDIVIDUAL PRICE INDICES

Precious metals

Gold

0.068

0.85

Silver $(*)$

0.064

0.35

Metals

$\begin{array}{lll}\text { Aluminium } & 0.027 & 0.99 \\ \text { Bauxite(*) } & 0.015 & 1.54 \\ \text { Copper } & 0.055 & 0.86 \\ \text { Iron } & 0.054 & 0.24 \\ \text { Lead } & 0.049 & 0.79 \\ \text { Nickel } & 0.021 & 1.18 \\ \text { Tin } & 0.021 & 0.51 \\ \text { Zinc } & 0.049 & 0.69\end{array}$

Agricultural raw materials

$\begin{array}{lrr}\text { Cotton }(*) & 0.096 & 0.43 \\ \text { Jute }(*) & 0.236 & -0.12 \\ \text { Rubber }(*) & 0.048 & 0.29 \\ \text { Wool } & 0.042 & 0.43\end{array}$

Food and tropical beverages

$\begin{array}{lrr}\text { Cocoa } & 0.029 & 0.99 \\ \text { Coffee } & 0.038 & 0.33 \\ \text { Maize(*) } & 0.086 & 0.26 \\ \text { Rice(*) } & 0.061 & 0.22 \\ \text { Soybeans } & 0.075 & 0.56 \\ \text { Sugar } & 0.038 & 1.05 \\ \text { Tea } & 0.139 & -0.05 \\ \text { Wheat } & 0.046 & 0.32\end{array}$

Notes: Regressions were done from 196202 to 198702 , except for commodity prices with a (*) for which regressions were done from 197001 to 198702 and gold prices (from 196501 and 1987Q2).

Sources are Intereconomics, Hamburg Weltwirtschaft Forschung Institüt for the HWWA indices, the U.N. Monthly Commodity Price Bulletin for the UNCTAD indices and the IMF, IFS Statistics for the IMF indices.

The critical value for the CRDW test below which first-order integration is rejected is 0.259 for 100 degrees of freedom $(0.493$ for 50 degrees of freedom). The critical value for the AFD test below which at least first-order integration is rejected is -3.45 for 100 degrees of freedom ( -3.50 for 50 degrees of freedom). 
Table 2

COINTEGRATION TESTS BETWEEN AGGREGATE COMMODITY

AND OECD PRICE LEVELS

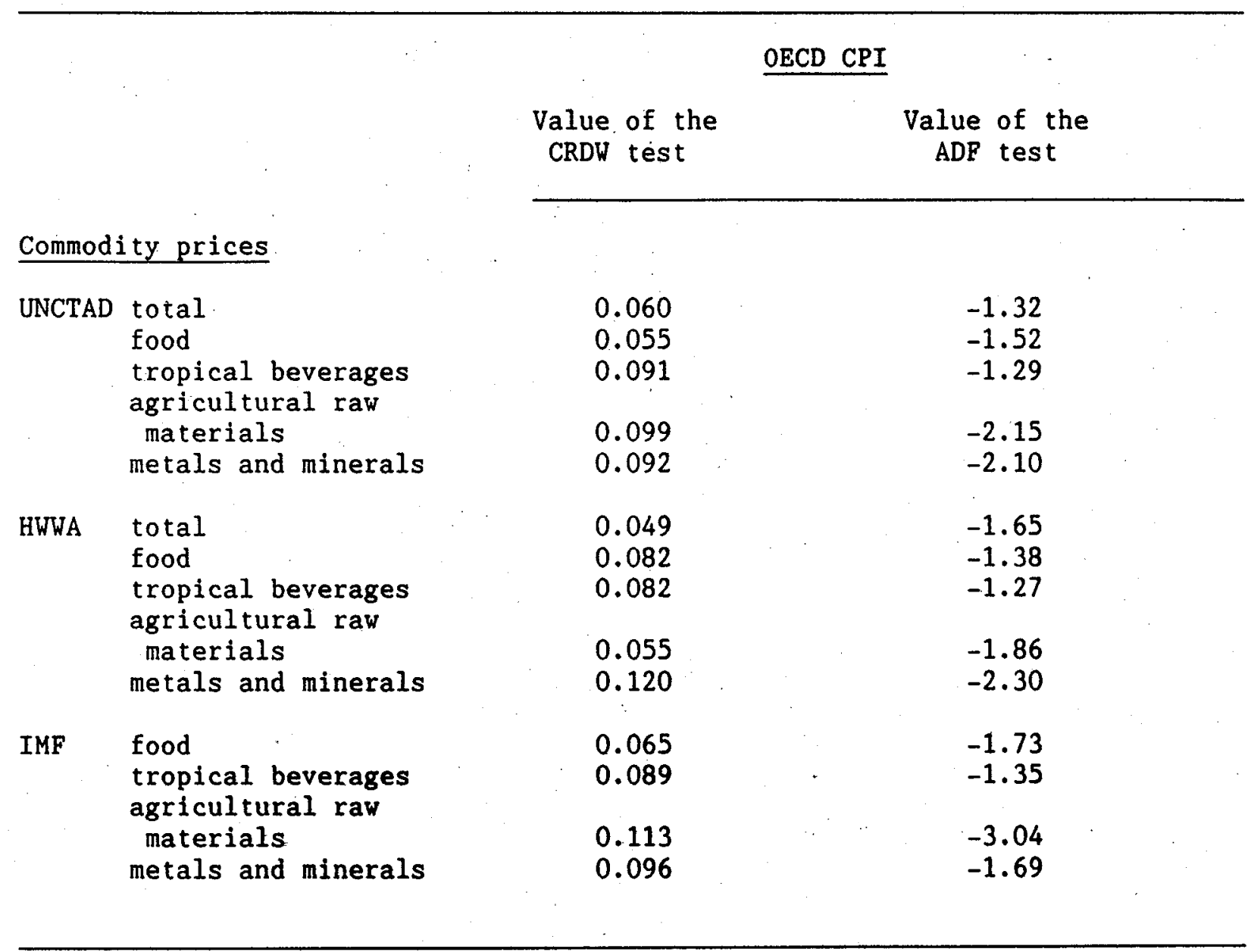

Note: The critical value for the CRDW test below which cointegration is rejected is 0.257 .

The critical value for the ADF test above which cointegration is rejected is -3.17 . 


\section{Granger-causality and stability tests}

Although it was not possible to find any level relationship between CPIs and commodity price indices, the fact that all indices are $I(1)$ is nevertheless an interesting result. Granger-causality [Granger (1969)] tests on the log-difference of the consumer and commodity price indices may provide information on possible temporal causality and feedback effects between rates of inflation in CPIs and commodity prices. If changes in commodity prices are useful indicators of future developments in CPI inflation, it is important to establish that commodity prices Granger-cause CPIs. On the other hand, if the tests reveal that commodity prices and CPIs Granger-cause each other, then it could be argued that they are both responding to a third variable such as a monetary aggregate(11).

The Granger-causality regressions took the standard vector autoregressive form:

$$
\begin{aligned}
& \Delta \operatorname{lnCPI} I_{t}=a_{0}+a_{1} \Delta \operatorname{lnPC}_{i},_{t-1}+a_{2} \Delta \operatorname{lnPC}_{i} l_{t-2}+a_{3} \Delta \operatorname{lnPC} i_{t-3}+a_{4} \Delta \operatorname{lnPC}_{1} t_{t-4}+ \\
& b_{1} \quad \Delta \ln C P I_{t-1}+b_{2} \Delta \operatorname{lnCPI} I_{t-2}+b_{3} \Delta \ln C P I_{t-3}+b_{4} \Delta \operatorname{lnCPI}_{t-4}+ \\
& d_{1} D Q_{1}+d_{2} D Q_{2}+d_{3} D_{3}+\varepsilon_{t} \\
& \Delta \operatorname{lnPC}{ }_{1}, t=c_{0}+c_{1} \Delta \operatorname{lnCPI} I_{t-1}+c_{2} \Delta \operatorname{lnCPI} I_{t-2}+c_{3} \Delta \ln \mathrm{CPI}_{\mathrm{t}-3}+c_{4} \Delta \ln \mathrm{CPI}_{\mathrm{t}-4}+ \\
& c_{1} \Delta \ln \mathrm{PC}_{1, t-1}+c_{2} \Delta \ln \mathrm{PC}_{1, t-2}+\mathrm{e}_{3} \Delta \ln \mathrm{PC}_{1, t-1}+\mathrm{e}_{4} \Delta \ln \mathrm{PC}_{1, t-4}+ \\
& d_{4} D Q_{1}+d_{5} D Q_{2}+d_{6} D Q_{3}+\mu_{t}
\end{aligned}
$$

where $\mathrm{PC}_{i}$ are commodity price indices, $\varepsilon$ and $\mu$ are error terms and $D Q_{1}, D_{2}$, and $\mathrm{DQ}_{3}$ are quarterly intercept dummies included to take care of seasonal variations which may be present in the series. Necessary conditions for $\mathrm{PC}_{1}$ to Granger-cause CPI without feedback from CPI to $\mathrm{PC}_{i}$ are that the following:

either $a_{1}, a_{2}, a_{3}$ or $a_{4}$ is non zero and

$$
c_{1}=c_{2}=c_{3}=c_{4}=0 \text {. }
$$

The first condition was tested using standard t-statistics and the second restriction was tested using the standard F-ratio test. If the former condition is accepted but the latter is rejected, then the variables are Granger-causing each other.

Table 3 summarizes the results of Granger-causality tests over the entire period (12). Average CPI inflation for the major seven countries can be predicted using available information in the past evolution of inflation in the aggregate prices of the UNCTAD agricultural raw materials and the HWWA metals and minerals. At the disaggregated levels, only changes in aluminium, sugar, maize and rice prices appear to be useful in predicting OECD inflation. Gold, which represents a particular case since its market is probably more speculative than the ones for other primary commodities, does not appear to be a good indicator of aggregate OECD inflation. It can however provide information in the prediction of the U.S. and the Italian inflation rates. 
Table 3

GRANGER-CAUSALITY TESTS ON COMMODITY PRICE INFLATION

AND MAJOR SEVEN OECD COUNTRIES CPI INFLATION

\begin{tabular}{llllllllll}
\hline USA & JAP & GER & FRA & UKM & ITA & CAN & Major 7 \\
CPI & CPI & CPI & CPI & CPI & CPI & CPI & CPI \\
\hline
\end{tabular}

A. AGGREGATE

COMMODITY PRICES

UNCTAD

\begin{tabular}{|c|c|c|c|c|c|c|c|}
\hline Total & $\mathbf{N}$ & $\mathbf{N}$ & $Y$ & $Y$ & $\mathbf{N}$ & $\mathrm{Y}$ & $\mathrm{N}$ \\
\hline Food & $\mathbf{N}$ & $\mathrm{Y}$ & $Y *$ & $Y$ & $\mathrm{Y}$ & $\mathrm{Y}$ & $\mathrm{N}$ \\
\hline $\begin{array}{l}\text { Tropical } \\
\text { beverages }\end{array}$ & $\mathrm{N}$ & $\mathbf{N}$ & $\mathbf{N}$ & $\mathbf{N}$ & $\mathbf{N}$ & $\mathrm{N}$ & $\mathbf{N}$ \\
\hline $\begin{array}{l}\text { Metals and } \\
\text { minerals } \\
\text { Agricultural }\end{array}$ & $Y$ & $\mathbf{N}$ & $\mathbf{N}$ & $\mathbf{N}$ & $\mathbf{N}$ & $\mathrm{N}$ & $\mathbf{N}$ \\
\hline raw materials & $\mathrm{Y}$ & $\mathbf{N}$ & $\mathbf{N}$ & $\mathbf{N}$ & $\mathrm{Y}$ & $N$ & $\mathbf{N}$ \\
\hline
\end{tabular}

HWWA

\begin{tabular}{|c|c|c|c|c|c|c|c|c|}
\hline Total & $\mathrm{N}$ & $\mathrm{N}$ & $\mathrm{N}$ & $\mathbf{N}$ & $\mathrm{N}$ & $\mathrm{N}$ & $\mathrm{N}$ & $N$ \\
\hline $\begin{array}{l}\text { Food } \\
\text { Tropical }\end{array}$ & $\mathrm{Y}$ & $\mathbf{Y}$ & $\mathbf{N}$ & $\mathbf{N}$ & N & $\mathbf{N}$ & $\mathrm{N}$ & $\mathrm{N}$ \\
\hline $\begin{array}{l}\text { beverages } \\
\text { Metals and }\end{array}$ & $\mathbf{N}$ & $\mathrm{N}$ & $\mathbf{Y}$ & $\mathbf{Y}$ & $\mathbf{N}$ & $\mathbf{N}$ & $\mathbf{N}$ & $\mathbf{N}$ \\
\hline $\begin{array}{l}\text { minerals } \\
\text { Agricultural }\end{array}$ & $\mathbf{N}$ & $\mathbf{N}$ & $\mathbf{N}$ & $\mathbf{N}$ & $\mathbf{N}$ & $\mathrm{N}$ & $\mathbf{N}$ & $\mathbf{Y}$ \\
\hline raw materials & $\mathbf{Y}$ & $Y *$ & $\mathbf{N}$ & $\mathbf{N}$ & $\mathbf{N}$ & $\mathrm{Y}$ & $\mathbf{N}$ & $\mathbf{N}$ \\
\hline IMF & & & & & & & & \\
\hline $\begin{array}{l}\text { Food } \\
\text { Tropical }\end{array}$ & $Y *$ & $Y *$ & $Y$ & $\mathbf{N}$ & $\mathbf{N}$ & $\mathbf{N}$ & $\mathbf{N}$ & $Y *$ \\
\hline $\begin{array}{l}\text { beverages } \\
\text { Metals and }\end{array}$ & $\mathbf{N}$ & $\mathbf{N}$ & $\mathbf{N}$ & $\mathbf{N}$ & $\mathbf{N}$ & $\mathbf{N}$ & $\mathbf{N}$ & $\mathbf{N}$ \\
\hline $\begin{array}{l}\text { minerals } \\
\text { Agricultural }\end{array}$ & $\mathbf{N}$ & $\mathbf{N}$ & $\mathbf{N}$ & $\mathbf{N}$ & $\mathbf{N}$ & $\mathbf{N}$ & $\mathrm{Y}$ & $\mathbf{N}$ \\
\hline raw materials & $Y *$ & $\mathbf{Y}$ & $\mathbf{N}$ & $\mathbf{N}$ & $\mathbf{N}$ & $Y$ & $\mathbf{N}$ & $Y *$ \\
\hline
\end{tabular}


Table 3 (Continued)

\begin{tabular}{lllllllll}
\hline USA & JAP & GER & FRA & UKM & ITA & CAN & Major 7 \\
& CPI & CPI & CPI & CPI & CPI & CPI & CPI & CPI \\
\hline
\end{tabular}

B. INDIVIDUAL

COMMODITY PRICES

\begin{tabular}{|c|c|c|c|c|c|c|c|c|}
\hline Gold & $Y$ & $\mathrm{~N}$ & $\mathrm{~N}$ & $\mathrm{~N}$ & $\mathrm{~N}$ & $\mathrm{Y}$ & $\mathrm{N}$ & $\mathrm{N}$ \\
\hline Aluminum & $\mathrm{N}$ & $\mathrm{N}$ & $Y$ & $\mathrm{~N}$ & $\mathrm{~N}$ & $Y *$ & $\mathrm{~N}$ & $\mathrm{Y}$ \\
\hline Coffee & $\mathrm{N}$ & N & $Y$ & N & N & $\mathrm{N}$ & $\mathrm{N}$ & $\mathrm{N}$ \\
\hline Copper & $Y^{*}$ & $\mathrm{~N}$ & $\mathrm{~N}$ & $\mathrm{Y}$ & $\mathrm{Y}$ & $\mathrm{N}$ & $\mathrm{Y}$ & $Y *$ \\
\hline Iron & $\mathrm{N}$ & $\mathrm{N}$ & $Y$ & $Y$ & $\mathbf{N}$ & $\mathrm{N}$ & $Y *$ & $\mathrm{~N}$ \\
\hline Lead & $\mathrm{N}$ & $Y$ & N & $\mathrm{N}$ & $\mathrm{N}$ & $Y$ & $\mathrm{Y}$ & $\mathrm{N}$ \\
\hline Nickel & $Y^{*}$ & $\mathrm{~N}$ & N & $\mathrm{N}$ & $Y *$ & $N$ & $\mathrm{~N}$ & $\mathrm{~N}$ \\
\hline Sugar & $\mathrm{N}$ & $\mathrm{N}$ & $\mathbf{N}$ & $\mathrm{Y}$ & $\mathrm{N}$ & $Y^{*}$ & $Y^{*}$ & $Y$ \\
\hline Tea & $\mathrm{N}$ & $\mathrm{N}$ & $\mathbf{N}$ & $\mathrm{N}$ & $\mathrm{N}$ & $\mathrm{N}$ & $\mathbf{N}$ & $\mathbf{N}$ \\
\hline Tin & $Y$ & $\mathrm{~N}$ & $Y$ & $Y$ & $Y^{*}$ & $\mathrm{~N}$ & $\mathrm{~N}$ & $\mathrm{~N}$ \\
\hline Wheat & $\mathrm{N}$ & $\mathrm{N}$ & $Y$ & $\mathrm{~N}$ & $\mathbf{N}$ & $N$ & N & $Y *$ \\
\hline Wool & $\mathrm{N}$ & $\mathrm{Y}$ & $\mathrm{N}$ & $\mathrm{N}$ & $\mathrm{N}$ & $Y$ & $\mathrm{~N}$ & $Y^{*}$ \\
\hline Zinc & $\mathrm{N}$ & $\mathrm{N}$ & $Y$ & $\mathrm{~N}$ & N & $\mathrm{N}$ & N & $Y^{*}$ \\
\hline Bauxi te & $\mathrm{N}$ & $\mathrm{N}$ & $\mathrm{N}$ & N & $\mathrm{N}$ & $Y^{*}$ & $\mathrm{Y}$ & $\mathbf{N}$ \\
\hline Cotton & $Y^{*}$ & $N$ & $\mathrm{~N}$ & $\mathrm{~N}$ & $\mathrm{~N}$ & $\mathrm{~N}$ & $\mathrm{~N}$ & $Y *$ \\
\hline Maize & $Y$ & $Y$ & $\mathrm{Y}$ & $\mathrm{N}$ & N & $Y$ & N & $\mathrm{Y}$ \\
\hline Rice & $\mathrm{N}$ & $\mathrm{N}$ & N & $\mathrm{N}$. & $\mathbf{N}$ & $\mathrm{N}$ & $\mathrm{Y}$ & $Y$ \\
\hline Rubber & $\mathrm{N}$ & $\mathrm{N}$ & $\mathbf{N}$ & $\mathrm{N}$ & $Y^{*}$ & $\mathbf{N}$ & $\mathrm{N}$ & $\mathbf{N}$ \\
\hline Silver & $Y^{*}$ & $\mathrm{~N}$ & $\mathbf{N}$ & $\mathrm{N}$ & $\mathrm{N}$ & $\mathrm{N}$ & $Y$ & $\mathbf{N}$ \\
\hline Soybeans & $Y *$ & $\mathrm{~N}$ & $Y *$ & $Y *$ & $\mathbf{N}$ & $\mathbf{N}$ & $\mathrm{N}$ & N \\
\hline Cocoa & $\mathrm{N}$ & $\mathbf{N}$ & $\mathrm{N}$ & $\mathrm{N}$ & N & $Y$ & $\mathbf{N}$ & $\mathrm{N}$ \\
\hline Jute & $\mathrm{Y}$ & $\mathbf{N}$ & $N$ & $\mathbf{N}$ & $\mathbf{N}$ & $Y$ & $\mathbf{N}$ & $\mathrm{N}$ \\
\hline
\end{tabular}

Note: $Y$ indicates that a commodity price Granger-causes the country CPI and $Y *$ indicates the presence of feedback effects.

$\mathrm{N}$ indicates that commodity prices do not Granger-cause CPIs. 
Finally, Hendry (1980) predictive failure tests have been carried out to determine if the CPI forecasting equations were stable over time. This test involves comparing the in- and out-of-sample variances of the first Granger-causality regressions; this was done for all of the bivariate relationships summarised in Table 3. Based on regressions from 1962 to 1973 and from 1974 to 1984, predictions were calculated for the periods after 1973 and 1984, respectively: For most commodity price indices which Granger-cause a country CPI without feedback in each of the two sub-samples, the stability test rejects the hypothesis of no predictive failure. This means that in most cases when a relationship between inflation rates in commodity price and consumer price indices exists, this relationship is generally unstable over time. For example, over the full sample period, the UNCTAD agricultural raw materials and the HWWA metals and minerals indices Granger-caused OECD inflation (as indicated by the "Y" in Table 3); however in both cases the Hendry tests indicate that predictive failure cannot be rejected (Table 4). Over the 1974-84 sub-sample, both the UNCTAD and HWWA indices of agricultural raw materials and metals and minerals Granger-cause OECD inflation; but predictive failure is rejected only for HWWA metals and minerals (Table 4). 
Table 4

STABILITY TESTS FOR OECD INFLATION

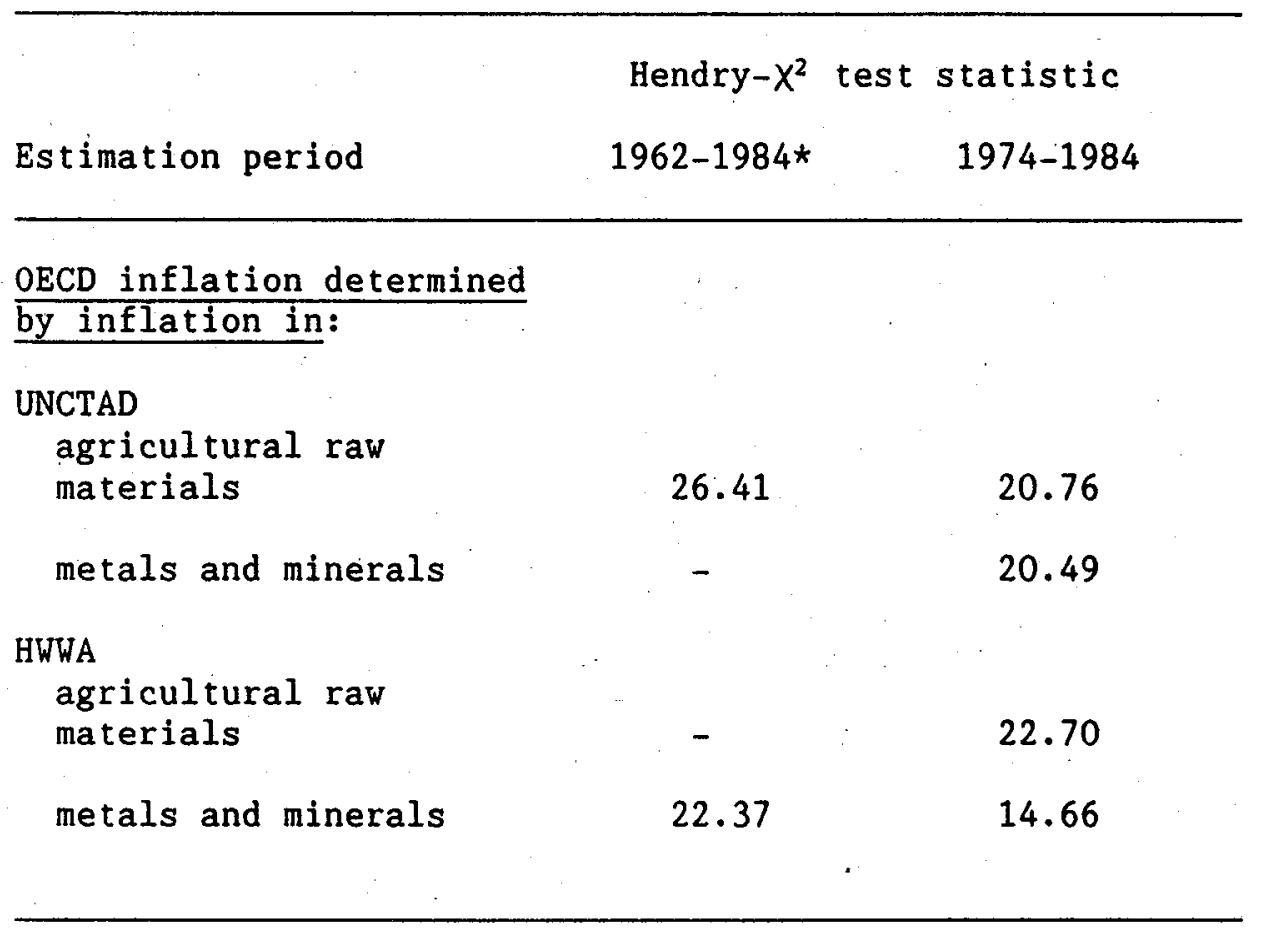

Note: The critical value of the Hendry- $\chi^{2}$ test below which predictive failure is rejected is 18.3 for ten degrees of freedom.

* Regressions were done from 196201 to 198404 and from 197401 to 198404 . Predictions were calculated from 198501 to 198702 . 
1. Such a specification is used in the Secretariat's INTERLINK model (see Stiehler, 1987).

2. In contrast to previous work by the OECD Secretariat [Holtham and Durand (1987) and Holtham, et al. (1985)] where multivariate relationships have been tested.

3. Econometric models which incorporate long-run relationships between jointly drifting variables typically assume their existence without testing for them. Instead, they impose prior constraints in the long-run in order to avoid relying on often spurious results from regressions with non-stationary variables.

4. Cointegration tests have been applied by e.g. Hall (1986), Jenkinson (1986), Campbell and Schiller (1987). In Holtham and Durand (1987) cointegration tests have been conducted to specify the relationship between commodity prices and their main determinants.

5. Distribution tables for the CRDW and ADF statistics are provided in Sargan and Bhagava (1983), p. 157 and Fuller (1976), p. 373.

6. IMF total commodity index is not included in this study, because of availability problems.

7. For a detailed analysis of the construction of aggregate commodity price indices see Siddique (1984).

8. For instance, the aggregate metals and minerals price index include aluminium and tin prices. The tin market is very different from the aluminium market. Large surpluses in tin led to the creation of a buffer stock to regulate prices. It is therefore possible that aluminium and tin price indices move quite differently over time, although they are included in the same aggregate index.

9. Integration and cointegration tests were also carried out on untransformed values of the variables. This led to the same results as those described below.

10. For a small number of commodity prices, the ADF tests are close to the critical value, but in testing for integration of second order, the CRDW test and Dickey-Fuller. (DF) test with no lags may be more appropriate than the ADF test. Results for the sub-periods and for the second-order integration tests are not reported here but are available on request.

11. In Holtham et al. (1985) causality tests had been done to identify commodity prices determinants such as OECD prices; OECD activity and interest rates and a number of other variables.

12. Granger-causality has been tested over the two sub-periods with similar results to those reported in the text. 


\section{REFERENCES}

Baker, J.A. (1987), "Statement", IMF-IBRD Board of Governors, 1987 Annual Meetings, Press Release, No.50.

Beckerman, W. and T. Jenkinson (1986), "What stopped the inflation? unemployment or commodity prices?", Economic Journal, No. 96, pp. 39-54.

Bosworth, B.P. and R.Z. Lawrence (1982), "Commodity Prices and the New Inflation", Washington D.C.: Brookings Institution.

Box, G.E.P. and G.M. Jenkins (1976), "Time Series Analysis. Forecasting and Control", Revised Edition, San Francisco: Holden-Day.

Campbell, J.Y. and R.J. Shiller (1987), "Cointegration and tests of present value models", Journal of Political Economy, No. 95, pp. 1062-1088.

Chow, G.C. (1960), "Tests of equality between sets of coefficients in two linear regressions", Econometrica, No. 28, pp. 591-605.

Dickey, D.A. and W.A. Fuller (1979), "Distribution of the estimators for autoregressive time series with a unit root", Journal of the American Statistical Association, No. 74, pp. 427-431.

Engle, R.F. and C.W.J. Granger (1987) "Cointegration and error correction: representation, estimation, and testing", Econometrica, No. 55, pp. 251-276.

Evans, G.B.A. and N.E. Savin (1981), "Testing for unit roots: 1", Econometrica, No. 49, pp. 753-779.

Evans, G.B.A. and N.E. Savin (1984), "Testing for unit roots: 2", Econometrica, No. 52, pp. 1241-1269.

Frankel, J.A. and G.A. Hardouvelis (1983), "Commodity prices, overshooting, money surprises and Fed credibility", National Bureau of Economic Research, Working Paper No. 1121.

Fuller, W.A: (1976), Introduction to Statistical Time Series, New York. John Wiley.

Granger, C.W.J. (1969), "Investigating causal relations by econometric models and cross-spectral methods", Econometrica, No. 37, pp. 424-438.

Granger, C.W.J. (1986), "Developments in the study of cointegrated economic variables", Oxford Bulletin of Economics and Statistics, No. 48, pp. 213-228.

Hall, S.G. (1986), "An application of the Granger and Engle two-step estimation procedure to United Kingdom aggregate wage data", Oxford Bulletin of Economics and Statistics, No. 48, pp. 229-239. 
Hendry, D.F. (1980), "Predictive failure and econometric modelling in macroeconomies: the transactions demands for money", in P. Ormerod (ed.), Modelling the Economy, London, Heineman Educational Books.

Hendry, D.F. (1986), "Econometric modelling with cointegrated variables: An overview", Oxford Bulletin of Economics and Statistics, No. 48, pp. 201-212.

Holtham, G., T. Saavalaien, P. Saunders and H. Sutch (1985), "Commodity prices in INTERLINK", OECD Department of Economics and statistics Working Paper No.27 (November).

Holtham, G. and M. Durand (1987), "OECD economic activity and non-oil commodity prices: reduced-form equations for INTERLINK". OECD Department of Economics and Statistics Working Paper No.42 (June).

Jenkinson, T.J. (1986), "Testing neo-classical theories of labour demand: An application of cointegration techniques", 0xford Bulletin of Economics and Statistics, No. 48, pp. 241-251.

Lawson, N. (1987), "Statement", IMF-IBRD Board of Governors, 1987 Annual Meetings, Press Release, No.44.

McKinnon, R.I. (1984), "An international standard for monetary stabilization", Policy Analyses in International Economics, No. 8, Washington, D.C.: Institute for International Economics.

McKinnon, R.I. (1987), "Monetary and exchange rate policies for international financial stability: A proposal", Journal of Economic Perspectives, (forthcoming).

Nelson, C.R. and C.I. Plosser (1982), "Trends and random walks in macoreconomic time series. Some evidence and implications", Journal of Monetary Economics, No.10, pp. 139-162.

Phillips, P.C.B. (1986), "Understanding spurious regressions in econometrics", Journal of Econometrics, No. 33, pp. 311-340.

Phillips, P.C.B. (1987), "Time series regression with a unit root, Econometrica, No. 55, pp. 277-301.

Sargan, J.D. and A. Bhargava (1983), "Testing residuals from least squared regression for being generated by the gaussian random walk", Econometrica, No. 51; pp. 153-174.

Siddique, A.K.M (1984), "Commodity price indices: A historical and methodological review", Statistical Journal of the United Nations, No.2, pp. 255-283.

Stiehler, U. (1987), "Price determination in the major seven country models in INTERLINK", OECD. Department of Economics and Statistics Working Paper No.44 (July). 
Stock, J.H. (1987), "Asymptotic properties of least squares estimators of cointegrated vectors", Econometrica, No. 55, pp.1035-1056.

Van Duyne, C. (1979), "The macroeconomic effects of commodity market disruptions in open economies", Journal of International Economics, No. 9 , pp. 559-82.

Williamson, J. and M. Miller, (1987), "Targets and indicators: A blueprint for the international co-ordination of economic policy", Policy Analyses in International Economics, No. 22, Washington D.C., Instititute for International Economics. 